\title{
Phylogeography of Bellamya (Mollusca: Gastropoda: Viviparidae) snails on different continents: contrasting patterns of diversification in China and East Africa
}

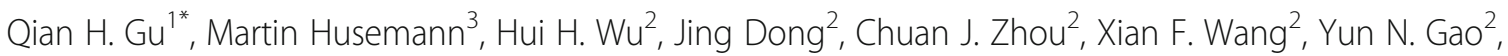
Man Zhang', Guo R. Zhu² and Guo X. Nie ${ }^{2}$

\begin{abstract}
Background: Species diversity is determined by both local environmental conditions that control differentiation and extinction and the outcome of large-scale processes that affect migration. The latter primarily comprises climatic change and dynamic landscape alteration. In the past few million years, both Southeast Asia and Eastern Africa experienced drastic climatic and geological oscillations: in Southeast Asia, especially in China, the Tibetan Plateau significantly rose up, and the flow of the Yangtze River was reversed. In East Africa, lakes and rivers experienced frequent range expansions and regressions due to the African mega-droughts. To test how such climatic and geological histories of both regions relate to their respective regional species and genetic diversity, a large scale comparative phylogeographic study is essential. Bellamya, a species rich freshwater snail genus that is widely distributed across China and East Africa, represents a suitable model system to address this question. We sequenced mitochondrial and nuclear DNA for members of the genus from China and used published sequences from Africa and some other locations in Asia to investigate their phylogeny and distribution of genetic diversity.

Results: Our phylogenetic analysis revealed two monophyletic groups, one in China and one in East Africa. Within the Chinese group, Bellamya species show little genetic differentiation. In contrast, we observe fairly deep divergence among the East African lakes with almost every lake possessing its unique clade. Our results show that strong divergence does not necessarily depend on intrinsic characteristics of a species, but rather is related to the landscape dynamics of a region.

Conclusion: Our phylogenetic results suggest that the Bellamya in China and East Africa are independent phylogenetic clades with different evolutionary trajectories. The different climate and geological histories likely contributed to the diverging evolutionary patterns. Repeated range expansions and regressions of lakes likely contributed to the great divergence of Bellamya in East Africa, while reversal of the river courses and intermingling of different lineages had an opposite effect on Bellamya diversification in China.
\end{abstract}

Keywords: Bellamya, 'out of Asia', Vicariance, Species radiation, Landscape dynamics

\footnotetext{
* Correspondence: qianhong_g@163.com

${ }^{1}$ State Key Laboratory of Developmental Biology of Freshwater Fish, College

of Life Sciences, Hunan Normal University, No. 36 Lushan Road, Changsha

City 410081, Hunan, People's Republic of China

Full list of author information is available at the end of the article
}

(c) The Author(s). 2019 Open Access This article is distributed under the terms of the Creative Commons Attribution 4.0 International License (http://creativecommons.org/licenses/by/4.0/), which permits unrestricted use, distribution, and reproduction in any medium, provided you give appropriate credit to the original author(s) and the source, provide a link to the Creative Commons license, and indicate if changes were made. The Creative Commons Public Domain Dedication waiver (http://creativecommons.org/publicdomain/zero/1.0/) applies to the data made available in this article, unless otherwise stated. 


\section{Background}

The roles that past climate fluctuations and geological events have played in species diversification and distribution are of main interest in phylo- and biogeography [1-3]. One major consequence of drastic climatic changes and geological activities are ecosystem and landscape reconfigurations. An example of a specifically large event is the drastic uplift of the Tibet Plateau and the resulting Asian monsoons, which largely re-shaped the landscape and affected the climate of eastern Asia [4-7]. These events are also considered an important driving force of vicariant speciation and intraspecific divergence in many freshwater species in the region [8-10], including salamanders and frogs [11-13]. Such rearrangements in the landscape can open up new migration corridors, facilitate the colonization of new habitats, and lead to novel species interactions [14]. The dynamic change of a landscape is considered one of the fundamental forces driving speciation $[15,16]$; yet, species life history traits also have an impact on the speciation rate [17-19]. Strong philopatry, low dispersal ability and specific breeding strategies promote rapid divergence of local populations $[20,21]$, whereas high dispersal leads to admixture and prevents such differentiation [22, 23].

A first step to identify the drivers of diversification is to establish a robust phylogeny. This approach is especially powerful when closely related taxa are compared. Close relatives are at early stages of their evolution, and their differences may still reflect independent selectional forces that had operated upon them.

As one of the widely distributed freshwater gastropods in Asia, India and Africa, Bellamya has been identified as relatively recent radiation [24, 25]. This is an optimal situation in order to test for the potential drivers of speciation in multiple geographic regions with different patterns of paleo-climatic fluctuations and geological events. Several other characteristics make Bellamya a great system to study the drivers of speciation: firstly, as freshwater gastropods, the large numbers of well-preserved shells serve as excellent fossil calibration points for molecular dating [24]. Secondly, their dispersal abilities are limited, rendering the passing of aquatic or terrestrial barriers difficult [26]. Thirdly, the fossils discovered in Southeast Asia [27], Mid-East [28, 29] and East Africa [14], suggest that Bellamya was found in these regions before the Pleistocene, when the climate oscillations were most intense. They can passively migrate by drainage evolution [30]. These characteristics offer excellent opportunities to test phylogeographic hypotheses and provide a powerful system to disentangle the relative importance of various climatic and geographic factors potentially involved in species diversification [31].

In this study, we chose the genus Bellamya, as our model system, to test how climatic and geological events have influenced the genetic diversity of this taxon on a large geographic scale. Bellamya is a species-rich genus of freshwater snails occurring in Asia, India and Africa $[24,25]$. Previous phylogenetic studies on the East African radiation have found that each of the great lakes possesses its own endemic species flock [24, 25]. The African and Asian species of Bellamya are sister groups with relatively low divergence contradicting an ancient Gondwanan vicariance [24]. However, little is known regarding the relationship within the Southeast Asian Bellamya lineage despite its diversitiy; at least 18 species have been reported from China [32].

Here we further investigate the relationships between Chinese and East African Bellamya lineages. Specifically, we intend to examine the patterns of diversification in Chinese and East African Bellamya lineages to test three hypotheses:

1) The Chinese and East African lineages represent monophyletic entities.

2) Similar to East Africa, Chinese Bellamya split into several distinct and isolated lineages.

3) Similar to other freshwater taxa, Bellamya originated in Africa and dispersed to Asia where it diverged from the African population due to strong geographic isolation.

\section{Results}

Geometrical morphology and ultrastructure of radulae Because of the low specimen number of B. lapillorum, $B$. lapidea and B. turritus $(\leq 6)$, five Bellamya species (for each $N \geq 20$ ), including $B$. quadrata, B. purificata, $B$. aeruginosa, $B$. angularis and $B$. dispiralis were used to compare the differences in shell morphology and the ultrastructure of radulae. Geometric morphometrics were used to examine shape variation through principal components analysis (PCA) and canonical variance analysis (CVA). The results showed that the first four PCs explain $60.01 \%$ of the variation in shell morphology (Additional file 1: Table S2), while the first two CVs explain $91.45 \%$ of the variation (Additional file 1: Table S3). The scatter plot of CV1 and CV2 showed clear differentiation between the five species (Fig. 1), and the results of Mahalanobis distances and Procrustes distances based on CVA showed a significant difference among the five Bellamya species in China $(P<0.01)$ (Additional file 1: Table S4).

The ultrastructure of radulae for the five species was examined using a scanning electron microscope (SEM, 800× magnification; Additional file 2: Figure S2a). The radulae were of stenoglossan type with a general formula of $2 \cdot 1 \cdot 1 \cdot 1 \cdot 2$; each row of radula teeth consisted of one central tooth, one lateral tooth and two marginal teeth on each side (Additional file 2: Figure S2a). Comparison 


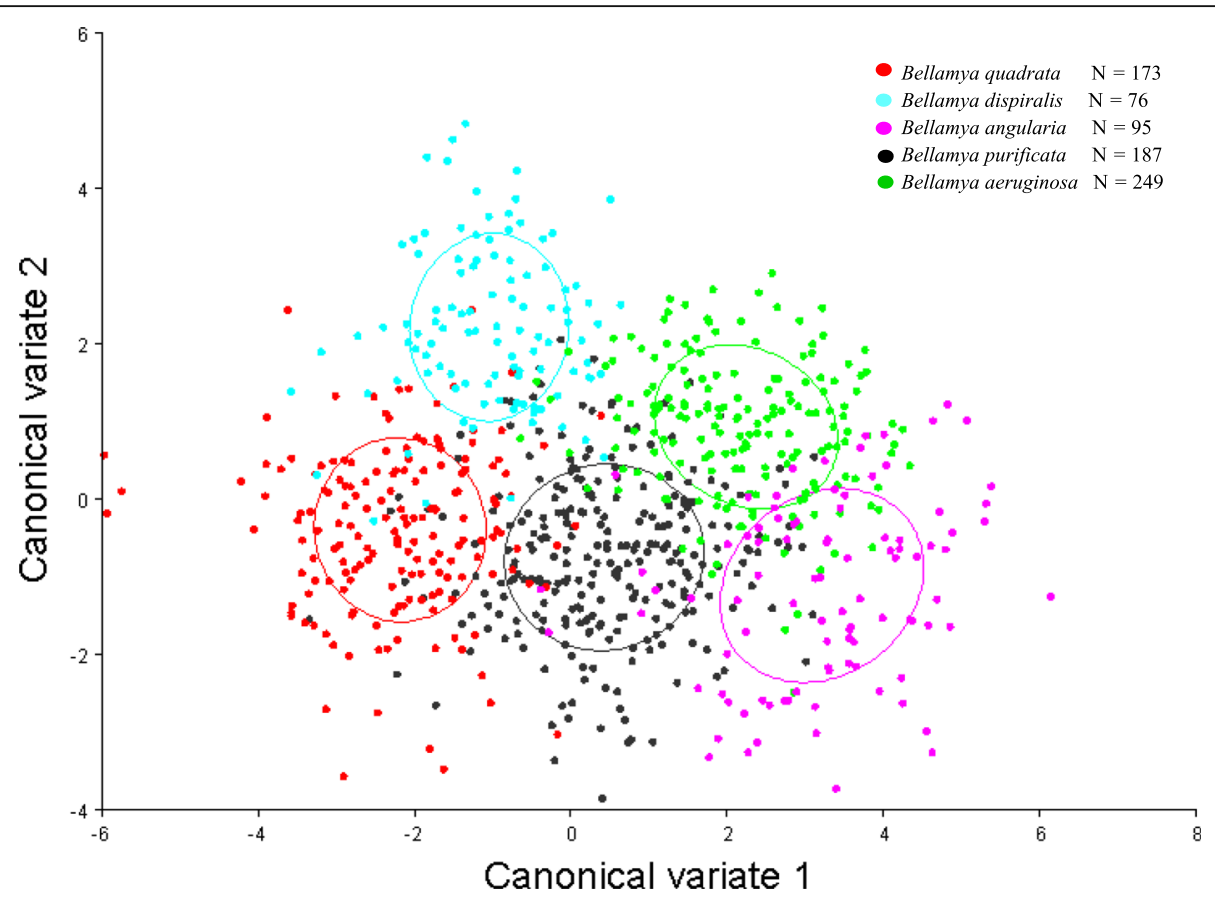

Fig. 1 Scatter plots from the Canonical Variate Analysis (CVA) for five Bellamya species from China, including Bellamya quadrata, B. dispiralis, B. angularia, B. purificata, B. aeruginosa, and number $(\mathrm{N})$ of each species was shown

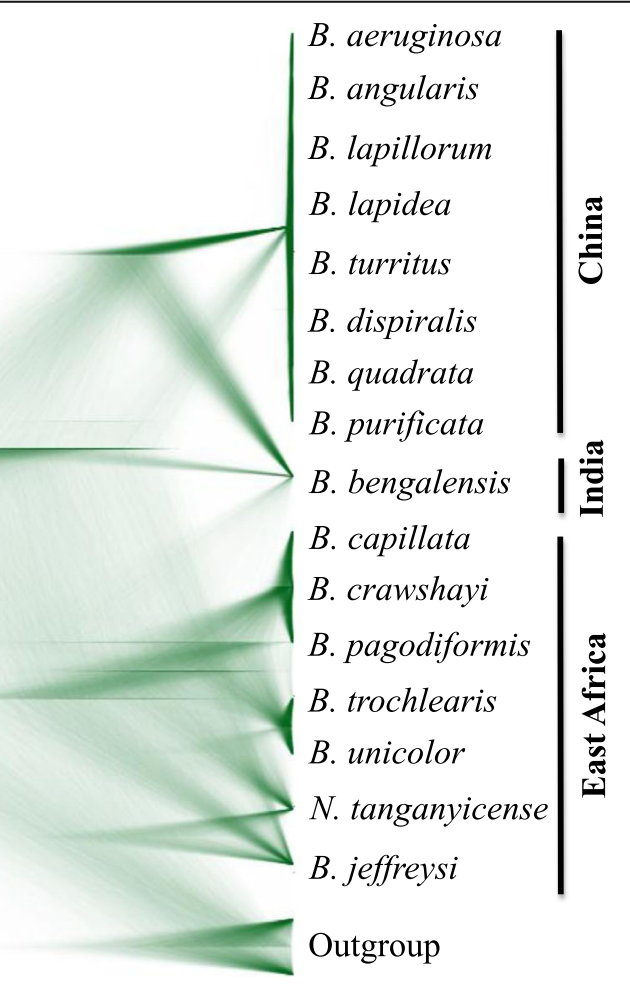

Fig. 2 Species tree of Bellamya constructed by BEAST visualized with DENSITREE. DENSITREE draws all trees gained from a Bayesian phylogenetic run using transparent lines. In areas where many trees agree on a specific topology and branch length, a densely colored area will be observed 
of the radular morphology revealed that the five Bellaymya species differed in their radula tooth formula, i.e. the number of central teeth, lateral teeth, inner marginal and outer marginal teeth (Additional file 1: Table S5, Additional file 2: Figure S2b).

\section{Sequence polymorphism}

A total of 319 individuals from 16 species were sampled. Due to sequencing failure for some genes the complete dataset of all 4 genes included 133 individuals. The datasets for the individual genes were larger: the COI dataset consisting of 295 sequences with a length of 658 bp. The alignment contained 166 (25.2\%) polymorphic sites, 136 (20.7\%) of which were parsimony informative. The 16S dataset contained 190 sequences each $508 \mathrm{bp}$ in length with $135(26.6 \%)$ variable sites, $108(21.3 \%)$ of which were parsimony informative. The nuclear genes were far less variable: the H3 dataset contained 159 sequences each $376 \mathrm{bp}$ with $34(9.0 \%)$ variable sites, 28 (7.4\%) of which were parsimony informative. We analyzed 189 sequences for the $28 \mathrm{~S}$ gene fragment, which were $391 \mathrm{bp}$ in length and contained only 24 variable sites (6.1\%), $13(3.3 \%)$ of which were parsimony informative.

\section{Species tree and haplotype network}

The resulting species tree showed a clear pattern of divergence between Africa and Asia (Fig. 2); all Bellamya species from China and East Africa formed own monophyletic clades with high support values as well as high posterior probabilities value (Additional file 3: Figure S3, ML phylogenetic). Bellamya species within East Africa showed a pattern of deep divergence and almost every lake formed its own unique genetic cluster. However, Bellamya species from China did not show any clear differentiation; different Bellamya species sampled from Northern to Southern parts of China formed a single genetic cluster.

The Median Joining Network showed two distinct matrilines (Additional file 4: Figure S4): one contained four main lake lineages from East Africa (Lake Vitoria, Lake Malawi, Lake Tanganyika and Lake Mweru); the second group is represented by a single highly admixed lineage from China and no differentiation could be detected.

\section{Phylogenetic tree construction and molecular clock estimates}

Our fossil calibrated molecular clock analyses and the rate calibrated analyses yielded fairly similar results. In the fossil calibrated analysis the Chinese Bellamya clade diverged from the East African one about 15.23 Ma (million years ago) (95\% confidence interval: 11.3-24.9 Ma) (Fig. 3a). The rate calibrated [33] analysis showed the same phylogenetic pattern and estimated the split between China and East Africa at approximately 20.68 Ma (CI: 15.3-28.2 Ma) (Fig. 3b). The divergence of the East African clades started between 8 (rate calibration) and $9 \mathrm{Ma}$ (fossil calibration) matching the evolution of the Lake Tanganyika basin between 9 and $12 \mathrm{Ma}$ [34]. The Chinese clade has formed between 4 (rate calibration) and $9 \mathrm{Ma}$ (fossil calibration).

\section{Discussion}

We sampled Bellamya species from China, India and East Africa, and employed phylogenetic and phylogeographic methods to investigate their divergence patterns. As we only included four specimens from India (Bellamya bengalensis IS01 IS04, see Additional file 5: Table S1), their diversity pattern will not be further discussed. We found two very different monophyletic lineages, one in China, the other in East Africa. However, the patterns of divergence on both continents represented two extremes with deep splits within East Africa and no significant genetic differentiation in China. In the following, we discuss our findings in the context of the geographic and climatic histories of the continents in detail.

\section{Monophyletic Chinese and east African lineages}

The eight Bellamya species collected in China can be identified according to their shell morphology characterized by Zhang and Liu (1960) [35]. Furthermore, there are significant differences in geometric characteristics of their shells and the ultrastructure of their radulae for five speceis of them.

Diversification of taxa distributed in Africa and Asia has received much attention and especially fish and snails have been extensively studied [36-38]. Our results suggest the presence of strong divergence between China and East Africa with monophyleltic clades with own evolutionary trajectories in both regions. In the East African lineage, based on molecular data, Sengupta et al. (2009) [24] reported seven putative species in accordance with taxonomic assignments [30]. In China, however, the eight species determined according to the current taxonomy could not be recovered with molecular data, and no significant differentiation between geographic populations was detected. Furthermore, we found no significant population genetic structure and phylogeographic pattern for both $B$. aeruginosa and B. purificata in China $[39,40]$.

Although two very different monophyletic lineages are found in China and East Africa, it is unknown whether the split between the Chinese and African populations is the result of vicariance or of long-distance dispersal. Many dispersal events between Africa and Asia have been reported and have been suggested to be the result of the contact between Africa and Eurasia via the 


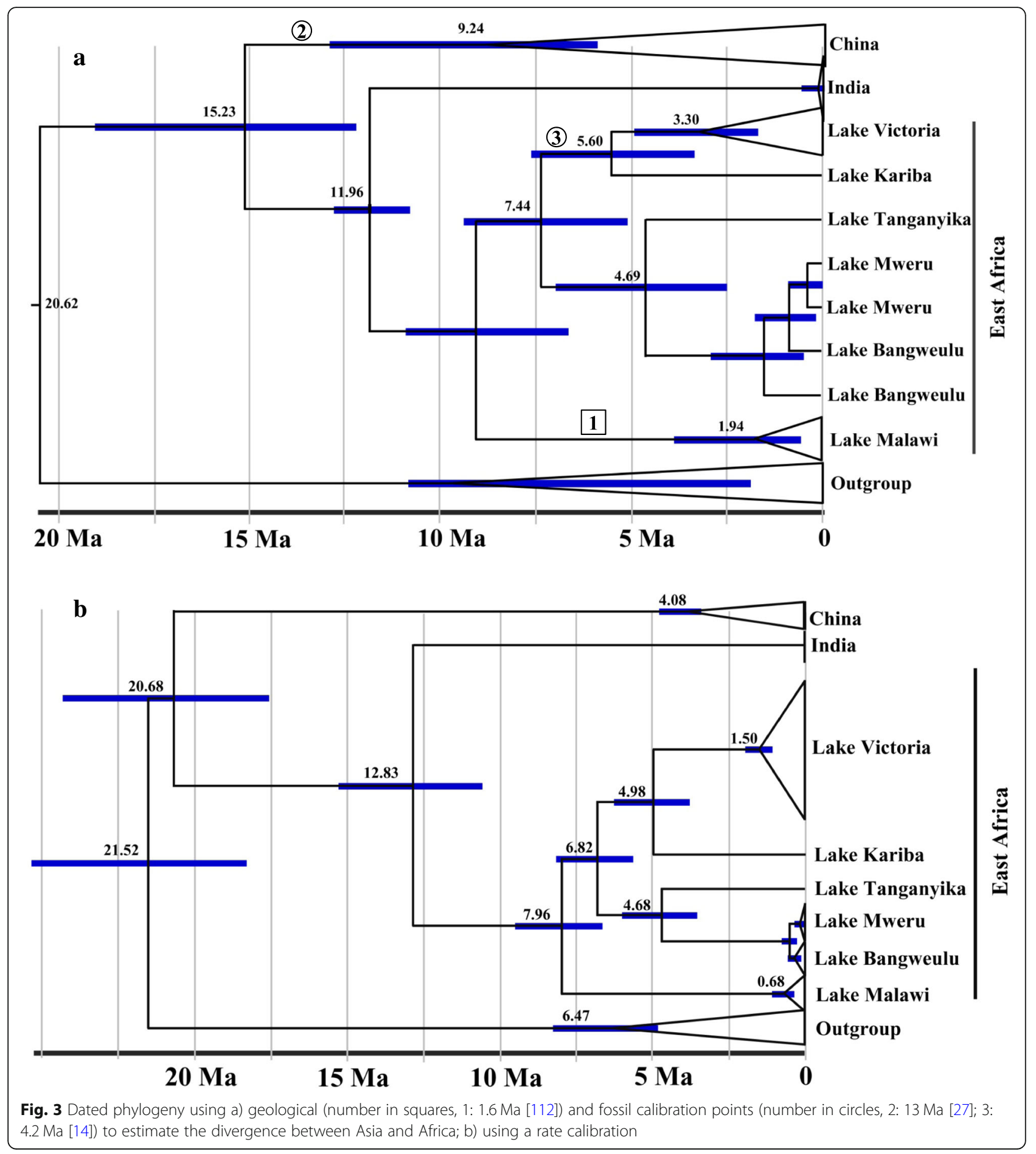

Arabian Peninsula about 20-15 million years ago (Ma) [41-43]. Many species migration events between the two continents have been postulated to have occurred at this time interval (between the late Oligocene and mid Miocene) [37, 44]. The results of the molecular clock analyses suggest that the divergence of the Chinese and the African lineages of Bellamya also occurred at that time and hence dispersal via the Indian route seems a likely scenario.

\section{Phylogrographic pattern}

Geological data indicates that India separated from Africa around $65 \mathrm{Ma}$ [45]. It subsequently collided with Asia between 20 and $55 \mathrm{Ma}$ depending on the model 
estimates [46-50]. Along with the uplift of Tibetan Plateau, the separation of India and Africa has created the most important biogeographical barriers that led to diversification events between Southeast Asia and India in many taxa [51], and also with other geographical regions, including the Middle East and Africa [52].

Our results suggested that East African Bellamya diverged from Chinese lineages during the early Miocene (approximately 20 15 Ma, Fig. 1a, b) when the Afro-Arabian plate and Eurasia became connected about 20.5-14.8 $\mathrm{Ma}$ [53]. The divergence time far preceded the time of the rapid uplift of Tibetan Plateau (10 8 Ma) [54] and even later $(3.6 \sim 0.8 \mathrm{Ma})$ [55], and far postdated the separation between India and Africa [45], suggesting that dispersal rather than vicariance has created the current distribution pattern of Bellamya in Southeast Asia and East Africa. Well dated Bellamya fossils have been recovered along Southeast Asia [56, 57] and the Middle-East [28], as well as from Africa [58], all postdating the Gondwana fragmentation [59]. This all suggests that the overland migration hypothesis is a good candidate explaining the distribution of Bellamya in Africa and Asia. The hypothesis of 'transoceanic long distance dispersal', proposed by Gittenberger (2012) [60], however, is a good alternative. Our data suggest that a Miocene dispersal event from Asia to Africa, through a broad connection between the Arabian Peninsula and Ethiopia $[42,61]$, was much more likely than an ancient Gondwanan vicariance based on the relatively low genetic diversity between the clades in Africa [14], while middle to high genetic diversity in COI was found in China [39, 40].

A strikingly similar pattern has been inferred from a phylogeny constructed for the family Viviparidae: the African viviparids are the sister group to a clade comprising Asian species (including Bellamya), and a similar dispersal route from Asia to Africa through the connection between Yemen and Ethiopia during middle and late Miocene was concluded [14]. Particularly, during the period of 10-8 Ma (late Miocene), sea levels dropped $60 \mathrm{~m}$ below modern levels, connecting Africa and the Arabian Peninsula by land bridges at either end of the Red Sea and facilitating the migration to Africa [62]. Bellamya entered Southeast Africa around $9 \mathrm{Ma}$ (Fig. 1a, b), and then dispersed to different water systems of East Africa, and continued to differentiate during Late Miocene and Pleistocene.

The Miocene seems to be the period during which Bellamya likely migrated from Asia for two reasons: Firstly, Bellamya fossils uncovered from Thailand [28] were dated at approximately $13 \mathrm{Ma}$ [27], which is earlier than the split time (9.18 7.96 Ma, Fig. 1a, b) of Bellamya in Africa, and also much earlier than any African fossils which were dated to the Early Pliocene, $4.2 \mathrm{Ma}$ [14] and that of Levant from the Pliocene-Pleistocene [29]; secondly, the climate during the Miocene was humid and warm, which allowed the rain forest to extent much further southward than today creating suitable habitat [63-65] for Bellayma, as well as for other gastropod species $[24,66,67]$. This was further corroborated by other taxa including fish and frogs [37, 41, 68].

However, the uprising of the Himalayan Mountain [54] and consequential climatic changes in the region started to impede species exchange during the Pleistocene, when the climate became much drier and cooler $[69,70]$. This had caused a retreat of rainforest cover which was replaced by savannahs and deserts in Southeast Asia [57]. These unfavorable climatic conditions made a subsequent dispersal of many freshwater organisms almost impossible. Consequently, this dry period may have initiated the isolation between African and Asian populations and led to the establishment of the genetically unique species in China and East Africa (Additional file 3: Figure S3 and Additional file 4: Figure S4).

The molecular phylogeny and fossil data strongly suggested that Bellamya originated in Southeast Asia. However, it was still in question how this genus invaded East Africa. It has been suggested that some freshwater gastropods, such as Pachychilidae, colonized Madagascar by trans-oceanic dispersal [71]. However, this type of dispersal was generally considered as unlikely due to large intercontinental distances and salinity intolerance of many invertebrates [72]. Yet, transportation of eggs or larvae by waterfowl remains a viable dispersal route. However, colonization on terrestrial routes appears more plausible. A possible migration route would have been through India and the Arabian Peninsula (Additional file 6: Figure S5), when Africa and Arabia were in close contact during the Miocene [73]. Certainly, this migration route should be further investigated by including additional specimens and sampling locations across the Asia, India, the Arabian Peninsula and Africa in the future, as well as more Bellamya fossils. Similar species exchanges have been demonstrated for other organisms at that time [73-76]. The increasingly arid conditions on the Arabian Peninsula between 7 and $8 \mathrm{Ma}$ [74] may have restricted dispersal subsequently, further accelerating the independent diversification of the East African and Chinese Bellamya.

\section{Contrasting patterns of divergence in Chinese and east African lineages}

It is well established that distribution patterns of aquatic biota often correlate with the geomorphological features of a region and its geologic history [77-79]. We observed contrasting divergence patterns in the monophyletic Bellamya lineages of China and East Africa. These patterns were likely associated with the divergent climatic and geological histories of the two regions. The collision between the 
Indian and Asian plates [46] had uplifted the Qinghai-Tibetan Plateau from around $1000 \mathrm{~m}$ to $4000-5000 \mathrm{~m}$ above sea level approximately in the middle and late Miocene and even more recently $[54,55]$. This collision had caused profound changes of the trajectories of many major rivers and geomorphological features in this region [55, 80]. The upper Yangtze River originally drained into the South China Sea through the Paleo-Red River until it was captured by the middle and lower reaches of the Yangtze River and reversed its route to flow into the East China Sea [81, 82]. The resulting river capture and flow reversal events, in turn, likely had a dramatic effect on the evolution of many aquatic organisms, including Bellamya. These events might have promoted genetic exchange between previously isolated Bellamya lineages, and would have resulted in range expansions of lineages which may previously have evolved in isolation removing any geographic signatures. Many tributaries flowed into the main river channel and numerous lakes interlace with them and formed a complete riverine-lacustrine network [83]. The newly established connectivity likely facilitated gene flow between different Bellamya populations, supported by the medium to high migration rates found in the $B$. aeruginosa across China [39]. Furthermore, the flooding, anthropogenic translocations and animal-mediated dispersal via waterfowl [84] would also expedite gene flow and obscure phylogeographic patterns in China $[39,40]$. Our analyses indicated that Chinese lineages of Bellamya had an onset of divergence estimated within the last 9 to $4 \mathrm{Ma}$. This estimate might even be inflated by the presence of ancestral polymorphisms and the actual age of many lineages might be even younger [85]. This is supported by the young age of most Bellamya fossil recovered from China, most of which were from the Holocene and Early Pleistocene [86-88]. Therefore, the Bellamya lineages in China, have not had sufficient time to accumulate mutations. Furthermore, gene flow between geographic populations and the possible occurrence of hybridization between sympatric species, which could not complete their lineage sorting, may have led to the observed lack of phylogenetic resolution in our data.

Similarly, East Africa underwent dramatic climatic and geological changes at the same period. Over the past few million years, the constant expansion and regression of the great East African lakes have led to the repeated formation and loss of habitats [89]. This landscape dynamics had dramatic effects on the organisms inhabiting in the lakes, including Bellamya [58]. However, these events caused an opposite effect on Bellamya evolution compared to their Chinese counterparts. Most of the East African lakes harbor their own endemic Bellamya lineages [24], which were also confirmed in our phylogenetic analysis. These lineages are most likely the results of relatively strong isolation among these water bodies. Intralacustrine speciation could also be explained by the frequent water level fluctuations causing high speciation rates and driving rapid diversification [90]. The African mega-droughts caused strong water level changes and probably led to strong bottlenecks or even extinctions for many organisms living in the shallow parts of the lakes. Lake Malawi, for example, was much shallower than today before $\sim 0.8 \mathrm{Ma}$ and experienced larger environmental fluctuations during that time [3]. The lake regression created empty ecological niches allowing for a secondary species radiations when the climate became favorable again [25]. The divergence time of the Lake Malawi lineage was dated at around $0.68 \mathrm{Ma}$, consistent with the refilling of the basin [72] and the radiation of another gastropod Lanistes in the lake [91].

\section{Conclusions}

Bellamya represents an ideal system to test how past climatic and geological events impacted current biodiversity. Molecular phylogenetics indicate that Bellamya in China and East Africa represent genetically unique phylogenetic clades. Our molecular dating suggested that the Bellamya in East Africa diverged from China approximately $20 \mathrm{Ma}$, suggesting that dispersal rather than vicariance was responsible for the extant biogeographic pattern of Bellamya in Africa and Asia. The different divergence patterns of Bellamya on the different continents are mainly attributed to the contrasting climatic and geological events.

\section{Methods}

\section{Sample collection}

Bellamya is a genus of freshwater snails, belonging to family Viviparidae. It is widely distributed across Asia, India and Africa. Currently, 18 endemic species are described both in China [32] and Africa [24]. Here, we followed the species identifications which were described by Zhang and Liu (1960) [35], and collected eight common species of Bellamya from several lakes across China (Additional file 5: Table S1, Fig. 4).

In addition, published Bellamya sequences from species outside of China were obtained from GenBank. Overall, we obtained a balanced sampling with 8 described taxa sampled in China and seven from East Africa, while just one species from India. A complete overview of the taxon sampling is provided in Additional file 5: Table S1.

In order to test for morphometric difference of Bellamya in China, ensuring the reliability of classification, shell geometric morphometrics was used to examine shape variation through principal components analysis (PCA) and canonical variance analysis (CVA) in MorphoJ v. 2.0 [92]. Shells of Bellamya were photographed with a Nikon CoolPix 4500 and 19 landmarks (Additional file 7: Figure S1) were 


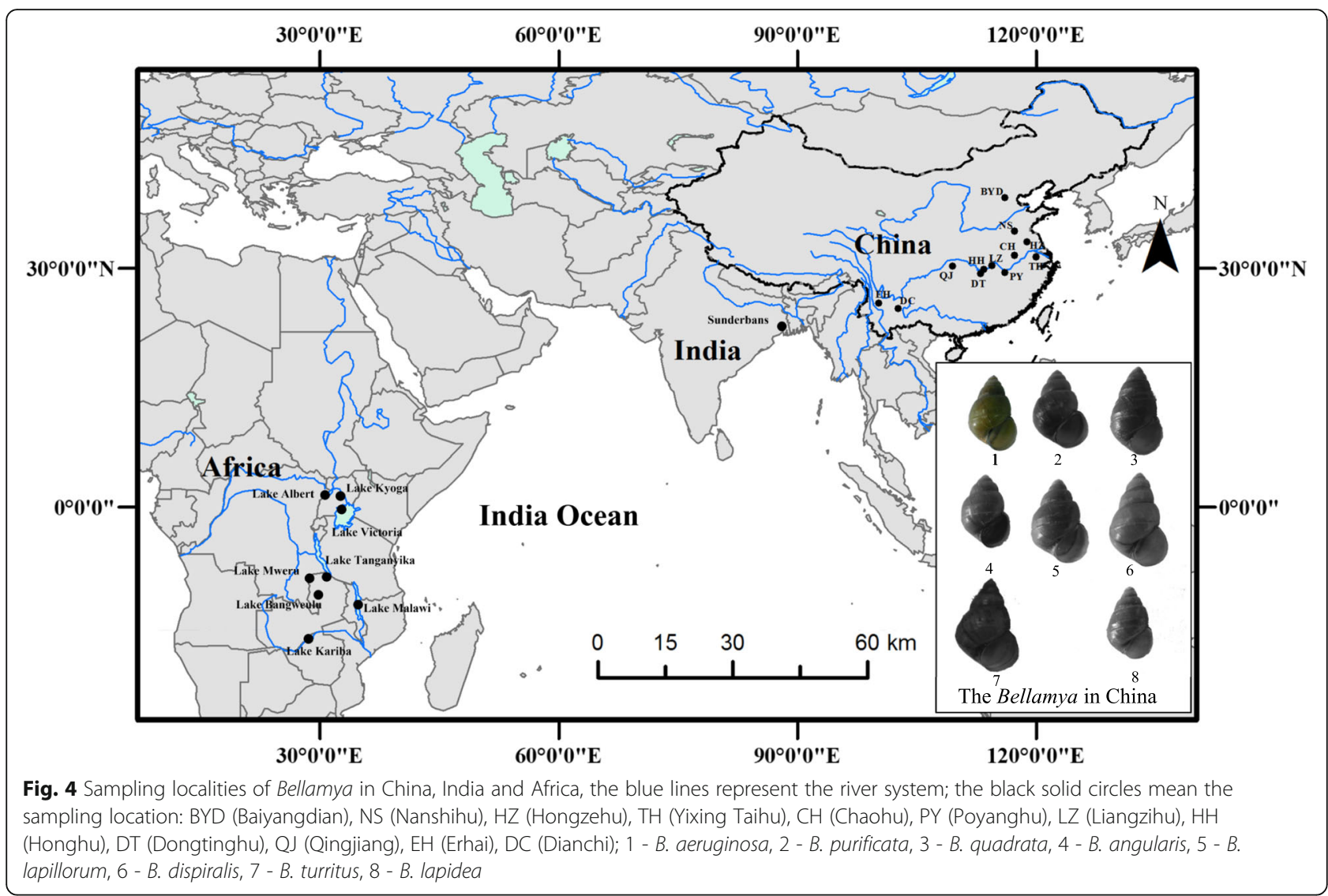

determined; $\mathrm{X}$ and $\mathrm{Y}$ coordinates were recorded according to Minton and Wang (2011) [93] by the software TpsDig2 [94]. For each specimen, the $\mathrm{X}$ and $\mathrm{Y}$ landmark coordinates were translated to the origin, rotated and scaled by the Generalized Procrustes Analysis [95] in TpsRelwarp [96] to remove non-shape variations. The specimen number of each species was more than 70 (the number of each species was shown in Fig. 1) in this study.

Furthermore, the radulae were investigated and compared using light and scanning electron microscope. The radulae were extracted from the snail buccal cavity using a stereomicroscope, and ten radulae of each species were examined. The radulae were first boiled in 5\% sodium hydroxide for $5 \mathrm{~min}$, and then washed in an ultrasonic scrubber for $2 \mathrm{~min}$. Dehydration was performed by immersing the radulae in increasing alcohol concentrations $(10,30,50,70,80$ and 95\%, respectively). Subsequently, the specimens were mounted on stubs with the help of a sharp-tipped needle on carbon conductive adhesive tapes. The stubs were then coated with gold and observed using a scanning electron microscope (AMRAY-1000B).

\section{DNA extraction, sequencing and molecular analyses}

Total genomic DNA was isolated from foot muscle tissue using the DNeasy kit following the manufacturer's protocol (QIAGEN DNeasy ${ }^{\circ}$ Blood and Tissue Kit, Shanghai, China). DNA was subsequently quantified with a spectrophotometer (NanoDrop 2000, Thermo Fisher Scientific, America). Four gene fragments were amplified by polymerase chain reaction (PCR): two mitochondrial genes (Cytochrome Oxidase I (COI) and 16S rRNA) and two partial nuclear genes (Histone $\mathrm{H} 3$ and $28 \mathrm{~S}$ rRNA). COI, $16 \mathrm{~S}$ and $\mathrm{H} 3$ were amplified using primers provided in the literature (COI - LCO1490 (forward primer) and HC02198 (reverse primer) [97], 16S - 16sar-L and 16sbr-H [98], and H3 - F (forward) and R (reverse) [99]). For 28S a new primer pair was designed with PRIMER Premier 5.0 (Premier Biosoft International, Palo Alto, California, USA) using various mollusk sequences deposited in GenBank (FJ405581-FJ405634): forward primer 5' -CCGCTGAATTTAAGCATATCACT-3' and reverse primer 5'-CGGTTTCACGTACTCTTGAACTC-3'. PCR was conducted in $50 \mu \mathrm{l}$ volume reactions using the PrimeSTAR ${ }^{\circ}$ HS DNA Polymerase (TAKARA, Dalian in China), $5 \times$ PrimerSTAR ${ }^{\circ}$ Buffer $\left(\mathrm{Mg}^{2+}\right.$ plus), $10 \mu \mathrm{l}$; dNTP Mixture (each $2.5 \mathrm{mM}$ ), $4 \mu \mathrm{l}$; Primers, each $1 \mu \mathrm{l}$; DNA, $1 \mu \mathrm{l}$; PrimeSTAR ${ }^{\circ}$ HS DNA Polymerase $(2.5 \mathrm{U} / \mu \mathrm{l}), 0.5 \mu \mathrm{l}$, purified water up to $32.5 \mu$ l. Thermal cycling conditions were as follows: $94^{\circ} \mathrm{C}$ for $4 \mathrm{~min}, 35$ cycles of $98^{\circ} \mathrm{C}$ for $10 \mathrm{~s}$, annealing for $5 \mathrm{~s}$ and $72^{\circ} \mathrm{C}$ for $45 \mathrm{~s}$; cycling was terminated by $8 \mathrm{~min}$ of final extension at $72{ }^{\circ} \mathrm{C}$. The annealing 
temperatures were $50{ }^{\circ} \mathrm{C}, 48{ }^{\circ} \mathrm{C}, 54^{\circ} \mathrm{C}$, and $52^{\circ} \mathrm{C}$ for $\mathrm{COI}$, $16 \mathrm{~S}, \mathrm{H} 3$ and $28 \mathrm{~S}$, respectively. PCR products were purified using the High Pure Product Purification Kit (TAKARA). Cycle-sequencing reactions were performed using BigDye terminator v. 3.1 and analyzed using an ABI-PRISM 3730 sequencer at Sangon Biotech (Shanghai, China). Both DNA strands were sequenced for each of the gene fragments. Sequences were edited and aligned using both strands for confirmation with Geneious v. 5.6.5 [100]. All sequences were aligned with MAFFT [101] as implemented in Geneious and compared to available sequences in GenBank to confirm validity. The sequences were submitted to GenBank (accession numbers (KF535211-KF535893); details provided in Additional file 5: Table S1).

\section{General statistics and phylogenetic analyses}

General alignment statistics were calculated with DNASP v.5 [102]. To test our first hypothesis that samples from both continents represent monophyletic lineages and to estimate a species tree, we constructed a phylogeny analyzing all four genetic markers simultaneously using the coalescent-based approach implemented in "BEAST [103]. In the species tree analysis we included all 319 individuals (Additional file 5: Table S1). Viviparus ater, $V$. contectus and Neothauma tanganyicense were used as outgroups. The best-fitting substitution models for each gene fragment were determined by JMODELTEST v.2.1.4 [104]. The GTR + I + G model was chosen for COI and H3. The GTR + I model was determined to be most suitable for $28 \mathrm{~S}$. The GTR $+\mathrm{G}$ model was selected for the 16S. An input file for "BEAST was generated using the program BEAUTI v.1.7.4 [105]. The Yule process was chosen as the tree prior as suggested to be useful for species level data [106] and the population size prior was set to constant. The analysis was run for 100 million generations to ensure convergence; trees were sampled every 10,000 generations. Convergence was checked in TRACER v1.7.1 [107] and inferred through the effective sample sizes (ESS) of parameters, which were all above 200. The first 1000 saved trees (10\%) were discarded as burn-in after ensuring the likelihood scores reached a plateau which was determined with the program TRACER v1.7.1 [107]. Trees were visualized in FIGTREE 1.4 [108] displaying posterior probabilities as branch support. Posterior probabilities above $95 \%$ were considered as evidence for substantial support at a node. A consensus tree was generated using TREEANNOTATOR v.1.6.1 [105] discarding a burn-in of $10 \%$. We further used DENSITREE 2.01 [109] to visualize the species tree. Densitree draws all trees gained from a "BEAST run using transparent lines. In areas where many trees agree on a specific topology and branch length, a densely colored area will be observed.
We also constructed a phylogenetic tree with the COI dataset using Maximum Likelihood (ML) and Bayesian analysis; here only COI was used, as almost all individuals were successfully sequenced for this gene. We tested the COI data for saturation using DAMBE v.5 [110]. The test revealed an Iss value that was significantly lower than the Iss.c in all cases $(P<0.0000)$, indicating the suitability of the COI data for phylogenetic analysis. The GTR+ G substitution model fitted the data best and was employed for the COI dataset. The ML tree was computed using RAxML 8.0 [111] with 1000 bootstrap replications to obtain branch support. A partitioned Bayesian analysis was conducted using MrBayes 3.2.2 [112] (Ronquist et al., 2012). Mixing of the MCMC chains of the two independent runs was monitored with TRACER v1.7.1 [107] and the analysis was terminated after the average standard deviation of the split frequencies fell under 0.01 . The first $10 \%$ of the sampled approximately 10 million generations were discarded as burn-in. The final trees were visualized in FIGTREE 1.4 [108].

To test our second hypotheses that several geographic lineages endemic to specific regions of Southeast Asia exist, we generated a haplotype network for the COI data (including all samples) and colored each haplotype by the geographic region from which it was collected. An unrooted network was constructed using network 4.6.0.0 and NETWORK PUBLISHER 1.3.0.0 (http:// www.fluxus-engineering.com/sharenet.htm) applying the median-joining and Maximum Parsimony options.

To test the third hypothesis that Bellamya originated in Africa and dispersed to Asia rather than a split by vicariance, divergence times were estimated using a molecular clock approach as implemented in "BEAST. We used the two mitochondrial genes (COI and 16S) and two nuclear genes (H3 and 28S) in this analysis (133 sequences) and employed a 'relaxed clock model' with two calibration points. The first calibration point was the timing of the East African mega-drought between 1.6-1.8 Ma, which almost desiccated Lake Malawi completely. The refilling of the lake about $1.6 \mathrm{Ma}$ was utilized as one calibration point for the Lake Malawi lineage [72]. The node was calibrated using a normal distribution with a mean at $1.6 \mathrm{Ma}$ and a standard deviation of $1 \mathrm{Ma}$. Bellamya fossil data was used as the second calibration point; fossil records were obtained from (1) Vichaidid et al. (2007) [27] from the Mae Moh basin, Thailand, which dates at approximately $13 \mathrm{Ma}$; (2) Van Bocxlaer et al. (2008) [14], and the Turkana basin in Kenya, dated at approximately 4.2 Ma. The analysis was run for 100 million generations logging trees every 10,000 generations. Convergence was checked with Tracer. Node ages are displayed together with 95\% highest posterior density bars indicating a range of age 
estimates. We performed a second molecular clock analyses with similar settings, but using a rate calibration. For this we used only the COI gene with a strict clock and a publishedrate of 0.0130 per Ma [33]. Viviparus ater (FJ405882), $V$. contectus (FJ405835) and Neothauma tanganyicense (FJ405843) served as outgroups for both analyses.

\section{Additional files}

Additional file 1: Table S2. Eigenvalues, percentage of variance and cumulative percentage of the first four principle components. Table S3. Eigenvalues, percentage of variance and cumulative percentage of the four canonical variate axes. Table S4. Differences based on geometric morphometrics of shell shape among five Bellamya species in China. Mahalanobis and Procrustes distances computed from the Canonical Variate analysis, $P$-values for the significance of the interspecies distances were computed using permutation tests (10,000 replications); all $P<$ 0.0001 . Table S5. Difference of radula ultrastructure of five Bellamya species in China, details in Additional file 7: Figure S1. (DOCX $21 \mathrm{~kb}$ )

Additional file 2: Figure S2. a) Scanning electron micrographs of the radulae of Bellamya; C, central teeth; L, lateral teeth; IM, inner marginal teeth; OM, outer marginal teeth; Scale bar $=100 \mu \mathrm{m}$. b) Radulae morphology of 5 Bellamya species. A, central tooth; B, lateral tooth; C, inner marginal tooth; D, outer marginal tooth; $1, B$. aeruginosa; $2, B$. purificata; 3, B. quadrata; 4, B. angularis; 5, B. dispiralis; Scale bar $=20 \mu \mathrm{m}$. (PPTX $663 \mathrm{~kb}$ )

Additional file 3: Figure S3. Phylogenetic tree of Bellamya generated from $\mathrm{COI}$ sequences constructed by RAxML 8.0. Numbers above the branches represent bootlstrap values (>50\%) for maximum likelihood estimations and the posterior probability (Bayesian inference, $\mathrm{Bl}>0.50$ ) calculated by Mrbayes. (PDF $606 \mathrm{~kb}$ )

Additional file 4: Figure S4. Median-joining haplotype network of 292 $\mathrm{COl}$ sequences. The size of the circles represents haplotype frequency. Each connecting line represents a single nucleotide substitution. Blue circles represent haplotype group 1 (Southeast Asia, numbers H38-138); red circles show haplotype group 2 (East Africa, numbers H1-37, except H16 and H37). In group 2, different colours represent different lake populations, Lake Malawi (red); Lake Victoria (rose red); Lake Kariba (purple); Lake Mweru (orange); Lake Tanganyika (green); Lake Bangwerulu (black); yellow represents Indian specimens ( $\mathrm{H} 16$ and $\mathrm{H} 37$ ). For sampling details please see Fig. 4 and Additional file 5: Table S1. (PPTX $498 \mathrm{~kb}$ )

Additional file 5: Table S1. Taxon sampling sites, sequence IDs, and GenBank accession numbers used in this study. (DOCX $81 \mathrm{~kb}$ )

Additional file 6: Figure S5. Inference of historical dispersion route and schematic view of the extant fossil record locations for Bellamya. Blue, orange and red indicate the possible distribution range of Bellamya in Asia, India and Africa. Arrows indicate the possible dispersion routes. Data were obtained from (1) Huang et al. (2007), Yixing, Jiangsu Province, China; (2) Wang (1983), Zhenpiyan, Guilin Province, China; (3) Vichaidid et al. (2007), Mae Moh basin, Thailand; (4) Ashkenazi et al. (2010), Gesher Benot Ya'aqov, Israel; (5) Sivan et al. (2006), Erq el-Ahmar, Israel; (6-10) Van Bocxlaer et al. (2008) and references therein. (PPTX $364 \mathrm{~kb}$ )

Additional file 7: Figure S1. Positions of 19 landmarks superimposed on a photograph of Bellamya. (PPTX $400 \mathrm{~kb}$ )

\section{Abbreviations}

16S: 165 ribosomal RNA; 28S: 285 ribosomal RNA; COI: Cytochrome C Oxidase Subunit I; ESS: The effective sample sizes; H3: Histone H3; Ma: Million years; MJ network: Median Joining Network

\section{Acknowledgements}

We thank Dr. Baoging Ding and another four reviewers for valuable comments on previous versions of the manuscript.

\section{Funding}

Funding was provided by the National Science Foundation of China (No. 31601851), the Initial Funding for the Initial Funding for the Doctor of Henan Normal University (No. qd13055) and the Innovation Scientists and Technicians Troop Construction Projects of Henan Province (No. CXTD2016043).

Availability of data and materials

The datasets analyzed during the current study are available in the Genbank (https://www.ncbi.nlm.nih.gov/genbank/).

Authors' contributions

QHG conceived the ideas; QHG, MH, HHW, JD, CJZ, XFW, YNG, MZ, and GRZ equally contributed to the writing of this manuscript. All authors read and approved the final manuscript.

\section{Ethics approval and consent to participate}

Not applicable.

\section{Consent for publication}

Not applicable.

\section{Competing interests}

The authors declare that they have no competing interests.

\section{Publisher's Note}

Springer Nature remains neutral with regard to jurisdictional claims in published maps and institutional affiliations.

\section{Author details}

'State Key Laboratory of Developmental Biology of Freshwater Fish, College of Life Sciences, Hunan Normal University, No. 36 Lushan Road, Changsha City 410081, Hunan, People's Republic of China. ${ }^{2}$ College of Fisheries, Engineering Technology Research Center of Henan Province for Aquatic Animal Cultivation, Henan Normal University, Xinxiang 453007, Henan, People's Republic of China. ${ }^{3}$ Centrum für Naturkunde, Universität Hamburg, 20146 Hamburg, Germany.

Received: 19 May 2018 Accepted: 22 February 2019

Published online: 21 March 2019

\section{References}

1. Rull V. Neotropical biodiversity: timing and potential drivers. Trends Ecol Evol. 2011;26:508-13 https://doi.org/10.1016/j.tree.2011.05.011.

2. Husemann M, Guzman NV, Danley PD, Cigliano MM, Confalonieri VA. Biogeography of Trimerotropis pallidipennis (Acrididae: Oedipodinae): deep divergence across the Americas. J Biogeogr. 2013;40:261-73 https://doi.org/ 10.1111/jbi.12007

3. Ivory SJ, Blome MW, King JW, McGlue MM, Cole JE, Cohen AS. Environmental change explains cichlid adaptive radiation at Lake Malawi over the past 1.2 million years. Proc Natl Acad Sci. 2016;113:11895-900 https://doi.org/10.1073/pnas.1611028113.

4. Sun XJ, Wang PX. How old is the Asian monsoon system?-Palaeobotanical records from China. Palaeogeogr Palaeocl. 2005;222:181-222 https://doi.org/ 10.1016/j.palaeo.2005.03.005

5. Clark MK, House MA, Royden LH, Whipple KX, Burchfiel BC, Zhang X, Tang W. Late Cenozoic uplift of southeastern Tibet. Geology. 2005;33:525-8 https://doi.org/10.1130/G21265.1.

6. Zhang R, Jiang DB, Liu XD, Tian ZP. Modeling the climate effects of different subregional uplifts within the Himalaya-Tibetan Plateau on Asian summer monsoon evolution. Chin Sci Bull. 2012;57:4617-26 https://doi.org/10.1007/ s11434-012-5284-y.

7. Yao G, Drew BT, Yi TS, Yan HF, Yuan YM, Ge XJ. Phylogenetic relationships, character evolution and biogeographic diversification of Pogostemon s.l. (Lamiaceae). Mol Phylogenet Evol. 2016;98:184-200 https://doi.org/10.1016/j. ympev.2016.01.020.

8. Yu D, Chen M, Tang QY, Li XJ, Liu HZ. Geological events and Pliocene climate fluctuations explain the phylogeographical pattern of the cold water fish Rhynchocypris oxycephalus (Cypriniformes: Cyprinidae) in China. BMC Evol Biol. 2014;14:225 https://doi.org/10.1186/s12862-014-0225-9. 
9. Guo XG, He SP, Zhang YG. Phylogeny and biogeography of Chinese sisorid catfishes re-examined using mitochondrial cytochrome $b$ and 165 rRNA gene sequences. Mol Phylogenet Evol. 2005;35:344-62 https://doi.org/10. 1016/j.ympev.2004.12.015.

10. Yang J, Yang JX, Chen XY. A re-examination of the molecular phylogeny and biogeography of the genus Schizothorax (Teleostei: Cyprinidae) through enhanced sampling, with emphasis on the species in the Yunnan- Guizhou plateau. China J Zool Syst Evol Res. 2012;50:184-91 https://doi.org/10.1111/j. 1439-0469.2012.00661.X.

11. Lu B, Zheng Y, Murphy RW, Zeng X. Coalescence patterns of endemic Tibetan species of stream salamanders (Hynobiidae: Batrachuperus). Mol Ecol. 2012;21(13):3308-24 https://doi.org/10.1111/j.1365-294X.2012.05606.X.

12. Yan F, Zhou W, Zhao H, Yuan Z, Wang Y, Jiang K, Jin J, Murphy RW, Che J, Zhang $Y$. Geological events play a larger role than Pleistocene climatic fluctuations in driving the genetic structure of Quasipaa Boulengeri (Anura: Dicroglossidae). Mol Ecol. 2013;22:1120-33 https://doi.org/10.1111/mec. 12153.

13. Zhang MW, Rao DQ, Yang JX, Yu GH, Wilkinson JA. Molecular phylogeography and population structure of a mid-elevation montane frog Leptobrachium Ailaonicum in a fragmented habitat of Southwest China. Mol Phylogenet Evol. 2010;54:47-58 https://doi.org/10.1016/j.ympev.2009.10.019.

14. Van Bocxlaer B, Damme DV, Feibel CS. Gradual versus punctuated equlibrium evolution in the Turkana basin Molluscs: evolutionary events or biological invasions? Evolution. 2008;62:511-20 https://doi.org/10.1111/j. 1558-5646.2007.00296.x.

15. Aguilée $R$, Claessen D, Lambert A. Adaptive radiation driven by the interplay of eco-evolutionary and landscape dynamics. Evolution. 2013;67:1291-306 https://doi.org/10.1111/evo.12008.

16. Yoichi W, Jin XF, Peng C, Tamaki I, Tomaru N. Contrasting diversification history between insular and continental species of three-leaved azaleas (Rhododendron sect. Brachycalyx) in East Asia. J Biogeogr. 2017;44:1065-76 https://doi.org/10.1111/jbi.12924.

17. Köhler F, Rintelen TV, Meyer A, Glaubrecht M. Multiple origin of Viviparity in southeast Asian gastropds (Cerithioidea: Pachychilidae) and its evolutionary implications. Evolution. 2004;58:2215-26 https://doi.org/10.1111/j.0014-3820. 2004.tb01599.x.

18. Michel E, Mcintyre PB, Chan J. A snail's space sets a snail's pace: movement rates of lavigeria gastropods in lake tanganyika, East Africa. J Mollus Stud. 2007;73:195-8 https://doi.org/10.1093/mollus/eym013.

19. Husemann M, Ray JW, King RS, Hooser EA, Danley PD. Comparative biogeography reveals differences in population genetic structure of five species of stream fishes. Biol J Linn Soc. 2012;107:867-85 https://doi.org/10. 1111/j.1095-8312.2012.01973.x.

20. Cohen AS, Johnston MR. Speciation in brooding and poorly dispersing lacustrine organisms. Palaios. 1987;2:426-35 https://doi.org/10.2307/3514614.

21. Vellend M, Geber MA. Connections between species diversity and genetic diversity. Ecol Lett. 2005;8:767-81 https://doi.org/10.1111/j.1461-0248.2005. 00775. .

22. Kasapidis P, Suchentrunk F, Magoulas A, Kotoulas G. The shaping of mitochondrial DNA phylogeographic patterns of the brown hare (Lepus europaeus) under the combined influence of Late Pleistocene climatic fluctuations and anthropogenic translocations. Mol Phylogenet Evol. 2005; 34:55-66 https://doi.org/10.1016/j.ympev.2004.09.007.

23. Ray JW, Husemann M, King RS, Danley PD. Genetic analysis reveals dispersal of Florida bass haplotypes from reservoirs to Rivers in Central Texas. T Am Fish Soc. 2012;141:1269-73 https://doi.org/10.1080/00028487.2012.690814.

24. Sengupta ME, Kristensen TK, Madsen H, Jørgensen A. Molecular phylogenetic investigations of the Viviparidae (Gastropoda: Caenogastropoda) in the lakes of the Rift Valley area of Africa. Mol Phylogenet Evol. 2009;52:797-805 https://doi.org/10.1016/j.ympev.2009.05. 007.

25. Schultheiss R, Wilke T, Jorgensen A, Albrecht $C$. The birth of an endemic species flock: demographic history of the Bellamya group (Gastropoda, Viviparidae) in Lake Malawi. Biol J Linn Soc. 2011;102:130-43 https://doi.org/ 10.1111/j.1095-8312.2010.01574.x.

26. Brown DS. Freshwater snails of Africa and their medical importance: Taylor and Francis Group; 1980.

27. Vichaidid T, Youngchuay U, Limsuwan P. Dating of aragonite fossil shell by ESR for paramagnetic species assignment of Mae Moh basin. Nucl Instrum Meth B. 2007;262:323-8 https://doi.org/10.1016/j.nimb.2007.05.021.
28. Ashkenazi S, Klass K, Mienis HK, Spiro B, Abel R. Fossil embryos and adult Viviparidae from the early-middle Pleistocene of Gesher Benot Ya'aqov, Israel: ecology, longevity and fecundity. Lethaia. 2010;43:116-27 https://doi. org/10.1111/j.1502-3931.2009.00178.x.

29. Sivan N, Heller J, Van Damme D. Fossil Viviparidae (Mollusca: Gastropoda) of the Levant. J Conchol. 2006;39:207-19 https://doi.org/10.1016/j.icesjms.2006. 09.001.

30. Schultheiß R, Van Bocxlaer B, Riedel F, von Rintelen T, Albrecht C. Disjunct distributions of freshwater snails testify to a central role of the Congo system in shaping biogeographical patterns in Africa. BMC Evol Biol. 2014; 14:42 https://doi.org/10.1186/1471-2148-14-42.

31. Szarowska M, Hofman S, Osikowski A, Falniowski A. Divergence preceding island formation among aegean insular populations of the freshwater snail genus Pseudorientalia (Caenogastropoda: Truncatelloidea). Zool Sci. 2014;31: 680-6 https://doi.org/10.2108/zs140070

32. Liu Y. Studies on the family Viviparidae in China (Mollusca, Gastropoda). Proceedings of the international Malacological congress (ed by Meier-Brook C.), Tübingen, Germany; 1989. pp: 587-592.

33. Wilke T, Schultheiß R, Albrecht C. As time Goes by: a simple Fool's guide to molecular clock approaches in invertebrates. Am Malacol Bull. 2009;27:2545 https://doi.org/10.4003/006.027.0203.

34. Salzburger W, Mack T, Verheyen E, Meyer A. Out of Tanganyika: genesis, explosive speciation, key-innovations and phylogeography of the haplochromine cichlid fishes. BMC Evol Biol. 2015;5:17 https://doi.org/10. 1186/1471-2148-5-17.

35. Zhang X, Liu Y. Morphology and habitat of common Bellamya in China. Bulletin of Biology. 1960;2:49-57 (in Chinese with English Abstract).

36. Chueca LJ, Gómez-Moliner BJ, Forés M, Madeira MJ. Biogeography and radiation of the land snail genus Xerocrassa (Geomitridae) in the Balearic Islands. J Biogeogr. 2017;44:760-72 https://doi.org/10.1111/jbi.12923.

37. Tang Q, Getahun A, Liu H. Multiple in-to-Africa dispersals of labeonin fishes (Teleostei: Cyprinidae) revealed by molecular phylogenetic analysis. Hydrobiologia. 2009;632:261-71 https://doi.org/10.1007/s10750-009-9848-Z.

38. Wang J, Wu XY, Chen ZM, Yue ZP, Ma W, Chen SY, et al. Molecular phylogeny of European and African Barbus and their West Asian relatives in the Cyprininae (Teleostei: Cypriniformes) and orogenesis of the QinghaiTibetan Plateau. Chin Sci Bull. 2013;58:3738-46 https://doi.org/10.1007/ s11434-013-5878-z.

39. Gu QH, Zhou CJ, Cheng QQ, Li XJ, Zhu GR, Zhang M, Gao YN, Dong J. The perplexing population genetic structure of Bellamya purificata (Mollusca: Gastropoda: Viviparidae): low genetic differentiation despite low dispersal ability. J Mollus Stud. 2015;81:466-75 https://doi.org/10.1093/mollus/eyv017.

40. Gu QH, Husemann M, Ding BQ, Luo Z, Xiong BX. Population genetic structure of Bellamya aeruginosa (Mollusca: Gastropoda: Viviparidae) in China: weak divergence across large geographic distances. Ecol Evol. 2015;5: 4906-19 https://doi.org/10.1002/ece3.1673.

41. Kosuch J, Vences M, Dubois A, Ohler A, Bohme W. Out of Asia: mitochondrial DNA evidence for an oriental origin of Tiger frogs, Genus Hoplobatrachus. Mol Phylogenet Evol. 2001;21:398-407 https://doi.org/10, 1006/mpev.2001.1034.

42. Popp M, Gizaw A, Nemomissa S, Suda J, Brochmann C. Colonization and diversification in the African 'sky islands' by Eurasian Lychnis $\mathrm{L}$. (Caryophyllaceae). J Biogeogr. 2008;35:1016-29 https://doi.org/10.1111/j. 1365-2699.2008.01902.x.

43. Zhou LL, Su YCF, Thomas DC, Saunders RMK. 'Out-of-Africa' dispersal of tropical floras during the Miocene climatic optimum: evidence from Uvaria (Annonaceae). J Biogeogr. 2011;39:322-35 https://doi.org/10.1111/j.13652699.2011.02598.x.

44. Portik DM, Papenfuss TJ. Historical biogeography resolves the origins of endemic Arabian toad lineages (Anura: Bufonidae): evidence for ancient vicariance and dispersal events with the horn of Africa and South Asia. BMC Evol Biol. 2015;15:152 https://doi.org/10.1186/s12862-015-0417-y.

45. Briggs JC. The biogeographic and tectonic history of India. J Biogeogr. 2003; 30:381-8 https://doi.org/10.1046/j.1365-2699.2003.00809.x.

46. Meng J, Wang C, Zhao X, Coe R, Li Y, Finn D. India-Asia collision was at $24^{\circ}$ $\mathrm{N}$ and $50 \mathrm{Ma}$ : palaeomagnetic proof from southernmost Asia. Sci Rep-UK. 2012;2:925 https://doi.org/10.1038/srep00925.

47. van Hinsbergen DJJ, Lippert PC, Dupont-Nivet G, McQuarrie N, Doubrovine PV, Spakman W, Torsvik TH. Greater India Basin hypothesis and a two-stage Cenozoic collision between India and Asia. Proc Natl Acad Sci. 2012;109: 7659-64 https://doi.org/10.1073/pnas.1117262109. 
48. Yang TS, Ma YM, Bian WW, Jin JJ, Zhang SH, Wu HC, Li HY, Yang ZY, Ding JK. Paleomagnetic results from the early cretaceous Lakang formation lavas: constraints on the paleolatitude of the Tethyan Himalaya and the India-Asia collision. Earth Planet Sci Lett. 2015;428:120-33 https://doi.org/10.1016/j.epsl. 2015.07.040

49. Yang TS, Ma YM, Zhang SH, Bian WW, Yang ZY, Wu HC, Li HY, Chen WW, Ding JK. New insights into the India-Asia collision process from cretaceous paleomagnetic and geochronologic results in the Lhasa terrane. Gondwana Res. 2015;28:625-41 https://doi.org/10.1016/j.gr.2014.06.010.

50. Zhu DC, Wang Q, Zhao ZD. Constraining quantitatively the timing and process of continent-continent collision using magmatic record: method and examples. Science China-Earth Sciences. 2017;60:1040-56 https://doi. org/10.1007/s11430-016-9041-x.

51. Renner SS. Available data point to a 4-km-high Tibetan Plateau by $40 \mathrm{Ma}$, but 100 molecular-clock papers have linked supposed recent uplift to young node ages. J Biogeogr. 2016;43:1479-87 https://doi.org/10.1111/jbi. 12755.

52. Pan T, Zhang Y, Wang H, Wu J, Kang X, Qian LF, Chen JY, Rao DQ, Jiang JP, Zhang BW. The reanalysis of biogeography of the Asian tree frog, Rhacophorus (Anura: Rhacophoridae): geographic shifts and climatic change influenced the dispersal process and diversification. PeerJ. 2017:5(11):e3995 https://doi.org/10.7717/peer.3995.

53. Otero O, Gayet M. Palaeoichthyofaunas from the lower Oligocene and Miocene of the Arabian Plate: palaeoecological and palaeobiogeographic implications. Palaeogeogr Palaeocl. 2001;165:141-69 https://doi.org/10.1016/ S0031-0182(00)00158-9.

54. Harrison TM, Copeland P, Kidd W, Yin A. Raising tibet. Science. 1992;255: 1663-70 https://doi.org/10.1126/science.255.5052.1663.

55. Ge XH, Liu JL, Ren SM, Yuan SH. Tectonic uplift of the Tibetan Plateau: impact on the fotmation of landforms, climate changes and ancient human migration in China. Geol China. 2014;41:698-714 (in Chinese with English abstract).

56. Wang HJ. Gastropods from the Zhenpiyan cave in Guilin, Guangxi. Acta Palaeontol Sin. 1983;22:483-5 (in Chinese with English abstract).

57. Songtham W, Ugai H, Imsamut S, Maranate S, Tansathien W, Meesook A, Saengsrichan W. Middle miocene molluscan assemblages in Mae Moh basin, Lampang province, Northern Thailand. Scienceasia. 2005;31:183-91 https://doi.org/10.2306/scienceasia1513-1874.2005.31.183.

58. Williamson P. Palaeontological documentation of speciation in Cenozoic molluscs from Turkana Basin. Nature. 1981;293:437-43 https://doi.org/10. 1038/293437a0

59. Ali JR, Aitchison JC. Gondwana to Asia: plate tectonics, paleogeography and the biological connectivity of the Indian sub-continent from the middle Jurassic through latest Eocene (166-35 Ma). Earth-Sci Rev. 2008;88:145-66 https://doi.org/10.1016/j.earscirev.2008.01.007.

60. Gittenberger E. Long-distance dispersal of molluscs:'their distribution at first perplexed me much'. J Biogeogr. 2012;39:10-1 https://doi.org/10.1111/j. 1365-2699.2011.02638.x.

61. Van Damme D, Van Bocxlaer B. Freshwater Molluscs of the Nile Basin, past and present. The Nile Springer Netherlands. 2009;89:585-629 https://doi. org/10.1007/978-1-4020-9726-3_29.

62. O'Brien SJ, Johnson WE. The evolution of cats. Sci Am. 2007;297:68-75 https://doi.org/10.1038/scientificamerican0707-68.

63. Bush MB, Flenley J. Tropical rainforest responses to climatic change. Joointly published with praxis publishing. UK: Springer; 2011.

64. Licht A, van Cappelle M, Abels HA, Ladant JB, Trabucho-Alexandre J, FranceLanord C, Donnadieu Y, Vandenberghe J, Rigaudier T, Lécuyer C, Terry D Jr, Adriaens R, Boura A, Guo Z, Soe AN, Quade J, Dupont-Nivet G, Jaeger JJ. Asian monsoons in a late Eocene greenhouse world. Nature. 2014;513:5016 https://doi.org/10.1038/nature13704.

65. Thomas DC, Chatrou LW, Stull GW, Johnson DM, Harris DJ, Thongpairoj U, Saunders RMK. The historical origins of palaeotropical intercontinental disjunctions in the pantropical flowering plant family Annonaceae. Perspect Plant Ecol. 2015;17:1-16 https://doi.org/10.1016/j.ppees.2014.11.001.

66. Kat P. Biogeography and evolution of African freshwater molluscs: implications of a Miocene assemblage from Rusinga Island. Kenya Palaeontology. 1987;30:733-42.

67. Köhler F, Glaubrecht M. Out of Asia and into India: on the molecular phylogeny and biogeography of the endemic freshwater gastropod Paracrostoma Cossmann, 1900 (Caenogastropoda: Pachychilidae). Biol J Linn Soc. 2007;91:627-51 https://doi.org/10.1111/j.1095-8312.2007.00866.x.
68. Li JT, Li Y, Klaus S, Rao DQ, Hillis DM, Zhang YP. Diversification of rhacophorid frogs provides evidence for accelerated faunal exchange between India and Eurasia during the Oligocene. Proc Natl Acad Sci. 2013; 110:3441-6 https://doi.org/10.1073/pnas.1300881110.

69. Zhisheng A, Kutzbach JE, Prell W, Porter SC. Evolution of Asian monsoons and phased uplift of the Himalaya-Tibetan plateau since Late Miocene times. Nature. 2001;411:62-6 https://doi.org/10.1038/35075035.

70. Xia MZ, Tian ZZ, Zhang FQ, Khan G, Gao QB, Xing R, Zhang Y, Yu JY, Chen $\mathrm{SL}$. Deep intraspecific divergence in the endemic herb Lancea tibetica (Mazaceae) distributed over the Qinghai-Tibetan Plateau. Front Genet. 2018; 125:62-77 https://doi.org/10.3389/fgene.2018.00492.

71. Köhler F, Glaubrecht M. Uncovering an overlooked radiation: molecular phylogeny and biogeography of Madagascar's endemic river snails (Caenogastropoda: Pachychilidae: Madagasikara gen. nov.). Biol J Linn Soc. 2010;99:867-94 https://doi.org/10.1111/j.1095-8312.2009.01390.x.

72. Van Damme D, Gautier A. Lacustrine mollusc radiations in the Lake Malawi Basin: experiments in a natural laboratory for evolution. Biogeosciences. 2013;10:5767-78 https://doi.org/10.5194/bg-10-5767-2013.

73. Bernor RL, Brunet M, Ginsburg L, Mein P, Pickford M, Rögl F, Sen S, Steininger $F$, Thomas $\mathrm{H}$. A consideration of some major topics concerning Old World Miocene mammalian chronology, migrations and paleogeography. Geobios. 1987;20:431-9 https://doi.org/10.1016/S00166995(87)80079-7.

74. Tchernov E. The Afro-Arabian component in the levantine mammalian fauna - a short biogeographical review. Israel J Zool. 1992;38:155-92 https:// doi.org/10.1080/00212210.1992.1068866.

75. Flynn $\sqcup$, Winkler AJ. Dispersalist implications of Paraulacodus indicus: a South Asian rodent of African affinity. Hist Biol. 1994;9:223-35 https://doi. org/10.1080/10292389409380499.

76. Stewart KM, Murray AM. Biogeographic implications of fossil fishes from the Awash River, Ethiopia. J Vertebr Paleontol. 2017;37:e1269115 https://doi.org/ 10.1080/02724634.2017.1269115

77. Benton MJ. The red queen and the court jester: species diversity and the role of biotic and abiotic factors through time. Science. 2009;323:728-32 https://doi.org/10.1126/science.1157719.

78. Inoue $\mathrm{K}$, Monroe EM, Elderkin CL, Berg DJ. Phylogeographic and population genetic analyses reveal Pleistocene isolation followed by high gene flow in a wide ranging, but endangered, freshwater mussel. Heredity. 2014;112:28290 https://doi.org/10.1038/hdy.2013.104.

79. Chen B, Long XP, Wilde SA, Yuan C, Wang Q, Xia XP, Zhang ZF. Delamination of lithospheric mantle evidenced by Cenozoic potassic rocks in Yunnan, SW China: a contribution to uplift of the Eastern Tibetan Plateau. Lithos. 2017;284:709-29 https://doi.org/10.1016/j.lithos.2017.05.019.

80. Stroeven AP, Hattestrand C, Heyman J, Harbor J, Li YX, Zhou LP, Caffee MW Alexanderson H, Kleman J, Ma HZ, Liu GN. Landscape analysis of the Huang He headwaters, NE Tibetan plateau - patterns of glacial and fluvial erosion. Geomorphology. 2009;103:212-26 https://doi.org/10.1016/j.geomorph.2008. 04.024.

81. Perdices A, Sayanda D, Coelho MM. Mitochondrial diversity of Opsariichthys bidens (Teleostei, Cyprinidae) in three Chinese drainages. Mol Phylogenet Evol. 2005;37:920-7 https://doi.org/10.1016/j.ympev.2005.04.020.

82. Ku XY, Zhou CJ, He SP. Validity of Pseudobagrus sinensis and mitochondrial DNA diversity of Pseudobagrus fulvidraco populations in China. Biodivers Sci. 2010;18:272-4 (in Chinese with English abstract).

83. Fu C, Wu J, Chen J, Wu Q, Lei G. Freshwater fish biodiversity in the Yangtze River basin of China: patterns, threats and conservation. Biodivers Conserv. 2003;12:1649-85 https://doi.org/10.1023/A:1023697714517.

84. Gittenberger E, Groenenberg DSJ, Kokshoorn B, Preece RC. Biogeography: molecular trails from hitchhiking snails. Nature. 2006;439:409 https://doi.org/ 10.1038/439409a.

85. Edwards S, Beerli P. Perspective: gene divergence, population divergence, and the variance in coalescence time in Phylogeographic studies. Evolution. 2000;54:1839-54 https://doi.org/10.1111/j.0014-3820.2000.tb01231.x.

86. Xue $C T$. Holocene sedimentary environments and sea levels change based on Qiongfeng section, Jianhu, Jiangsu, China. Acta Sedimentologia Sinica. 2002;20:174-7 (in Chinese with English Abstract).

87. Huang BY, Zhu XG, Cai HW, Lin LG, Tian ML. Holocene molluscs in Luotuodun and Xixi of Yixing City, Jiangsu Province. Marine Sciences. 2005: 29:84-94 (in Chinese with English abstract).

88. Wang SM. Some Pleistocene fresh water molluscan Faunules from North China. Acta Palaeontol Sin. 1961;9:80-91 (in Chinese with English abstract). 
89. Danley PD, Husemann M, Ding B, DiPietro LM, Beverly EJ, Peppe DJ. The impact of the geologic history and paleoclimate on the diversification of east African cichlids. Int J Evol Biol. 2012;2012:574851 https://doi.org/10. 1155/2012/574851.

90. Nevado B, Mautner S, Sturmbauer C, Verheyen E. Water-level fluctuations and metapopulation dynamics as drivers of genetic diversity in populations of three Tanganyikan cichlid fish species. Mol Ecol. 2013;22:3933-48 https:// doi.org/10.1111/mec.12374.

91. Schultheiss R, Van Bocxlaer B, Wilke T, Albrecht C. Old fossils-young species: evolutionary history of an endemic gastropod assemblage in Lake Malawi. $P$ R Soc B. 2009;276:2837-46 https://doi.org/10.1098/rspb.2009.1443.

92. Klingenberg CP. MorphoJ: an integrated software package for geometric morphometrics. Mol Ecol Resour. 2011;11:353-7 https://doi.org/10.1111/j. 1755-0998.2010.02924.x.

93. Minton RL, Wang LL. Evidence of sexual shape dimorphism in Viviparus (Gastropoda: Viviparidae). J Mollus Stud. 2011;77:315-7 https://doi.org/10. 1093/mollus/eyr014.

94. Rohlf FJ. tpsDig, digitize landmarks and outlines, version 2.05. State University of New York at Stony Brook: Department of Ecology and Evolution; 2005.

95. Rohlf FJ, Slice DE. Extensions of the Procrustes method for the optimal superimposition of landmarks. Syst Zool. 1990;39:40-59 https://doi.org/10. 2307/2992207

96. Rohlf FJ. tpsDig, tpsRegr, tpsRelw. Distributed by the author at http://life.bio. sunysb.edu/morph/. 2004-2007.

97. Folmer O, Black M, Hoeh W, Lutz R, Vrijenhoek R. DNA primers for amplification of mitochondrial cytochrome c oxidase subunit I from diverse metazoan invertebrates. Mol Mar Biol Biotechnol. 1994;3:294-9 https://doi. org/10.4028/www.scientific.net/DDF.7.460.

98. Palumbi S, Martin A, Romano S, McMillan WO, Stice L, Grabowski G. The simple fool's guide to PCR, version 2. Department of Zoology and Kewalo Marine Laboratory: University of Hawaii, Honolulu; 1991.

99. Colgan DJ, McLauchlan A, Wilson GDF, Livingston SP, Edgecombe GD, Macaranas J, Cassis G, Gray MR. Histone H3 and U2 snRNA DNA sequences and arthropod molecular evolution. Aust J Zool. 1998;46:419-37 https://doi. org/10.1071/ZO98048.

100. Drummond AJ, Ashton B, Buxton S, Cheung M, Cooper A, Duran C, Field M, Heled J, Kearse M, Markowitz S, Moir R, Stones-Havas S, Sturrock S, Thierer T, Wilson A. Geneious v5.6.5. Available from http://www.geneious.com. 2010.

101. Katoh K, Standley DM. MAFFT multiple sequence alignment software version 7: improvements in performance and usability. Mol Biol Evol. 2013; 30:772-80 https://doi.org/10.1093/molbev/mst010.

102. Librado P, Rozas J. DnaSP v5: a software for comprehensive analysis of DNA polymorphism data. Bioinformatics. 2009;25:1451-2 https://doi.org/10.1093/ bioinformatics/btp187.

103. Heled J, Drummond AJ. Bayesian inference of species trees from multilocus data. Mol Biol Evol. 2010;27(3):570-80. https://doi.org/10.1093/molbev/msp274.

104. Posada D. jModelTest: Phylogenetic Model Averaging. Mol Biol Evol. 2008;25: 1253-6 https://doi.org/10.1093/molbev/msn083.

105. Drummond AJ, Rambaut A. BEAST: Bayesian evolutionary analysis by sampling trees. BMC Evol Biol. 2007;7:214 https://doi.org/10.1186/1471-2148-7-214

106. Drummond AJ, Ho SYW, Phillips MJ, Rambaut A. Relaxed Phylogenetics and dating with confidence. PLoS Biol. 2006;4:e88 https://doi.org/10.1371/ journal.pbio.0040088.

107. Rambaut A, Drummond AJ, Xie D, Baele G, Suchard MA. Posterior summarisation in Bayesian phylogenetics using tracer 1.7. Syst Biol. 2018;67: 901-4 https://doi.org/10.1093/sysbio/syy032.

108. Rambaut A. FigTree v1.4.0: Tree Figure DrawingTool. Available: http://tree. bio.ed.ac.uk/software/figtree/. 2012.

109. Bouckaert RR. DensiTree: making sense of sets of phylogenetic trees. Bioinformatics. 2010;26:1372-3 https:/doi.org/10.1093/bioinformatics/bta110

110. Xia X. DAMBE5: a comprehensive software package for data analysis in molecular biology and evlution. Mol Biol Evol. 2013;30:1720-8 https://doi. org $/ 10.1093 / \mathrm{molbev} / \mathrm{mst064}$.

111. Stamatakis A. RAxML version 8: a tool for phylogenetic analysis and postanalysis of large phylogenies. Bioinformatics. 2014;30:1312-3 https://doi.org/ 10.1093/bioinformatics/btu033.

112. Ronquist F, Teslenko M, van der Mark P, Ayres DL, Darling A, Höhna S, Larget B, Liu L, Suchard MA, Huelsenbeck JP. MrBayes 3.2: efficient Bayesian phylogenetic inference and model choice across a large model space. Syst Biol. 2012;61:539-42 https://doi.org/10.1093/sysbio/sys029.

Ready to submit your research? Choose BMC and benefit from:

- fast, convenient online submission

- thorough peer review by experienced researchers in your field

- rapid publication on acceptance

- support for research data, including large and complex data types

- gold Open Access which fosters wider collaboration and increased citations

- maximum visibility for your research: over $100 \mathrm{M}$ website views per year

At BMC, research is always in progress.

Learn more biomedcentral.com/submissions 